\title{
Management of Education Facilities and Infrastructure
}

\author{
Noer Kamilatus Sholihah \\ Department of Educational Management \\ Universitas Negeri Surabaya \\ Surabaya, Indonesia \\ noer18016@mhs.unesa.ac.id
}

\begin{abstract}
The research focus is how the management of facilities and infrastructure at Wali Songo Pacet, Mojokerto Vocational High School. The research purpose is to describe the management of facilities and infrastructure at Wali Songo Pacet Mojokerto Vocational High School. This method uses a qualitative approach with case study research design. Data collection techniques using interview, observation, and documentation. The data analysis technique uses data reduction, data presentation, and conclusion. The research subject at Wali Songo Pacet, Mojokerto Vocational High School. The objects in this study are facilities and infrastructure at Wali Songo Pacet, Mojokerto Vocational High School. Based on the research results of the Wali Songo Pacet, Mojokerto Vocational High School the existing infrastructure is very adequate in supporting the education process. So, that whenever needed by school personnel always ready to use. The number of facilities owned by Wali Songo Pacet, Mojokerto Vocational High School is very relevant to the needs of students. The process of management of educational facilities and infrastructure at Wali Songo Pacet, Mojokerto Vocational High School, carried out sequentially starting with planning, procurement, maintenance, inventory and deletion.
\end{abstract}

Keyword-management; facilities and infrastructure; case study

\section{INTRODUCTION}

The era of revolution 4.0 requires a more mature readiness in everything. The field of education is one of the mainstays for preparing the human resources needed to face the challenges of today. Preparation of human resources in the field of education is carried out from the time of elementary, middle and high education. To meet expectations in the field of education, the role of educational infrastructure is very important, namely to facilitate the implementation of the teaching and learning process. On the one hand, the expectations imposed on the world of education are many, but on the other hand the world of education has many problems that hamper the implementation of teaching and learning activities in schools. One of the problems faced by schools is the problem of educational facilities. Problems with education facilities faced by schools, including educational support facilities are not yet fully in adequate conditions, this can be seen, for example, damaged learning facilities or not yet available. such conditions, in addition to having an effect on unfairness, discomfort in the teaching and learning process, will also have an impact on the reluctance of parents to send their children to these schools. In order to carry out tasks that are grouped as the substance of school supplies, it is necessary to have good management or management of facilities and infrastructure.

Management is the process of utilizing all resources in order to achieve the stated goals. The management of facilities and infrastructure is basically one of the fields of study of school management or education administration and at the same time is the main task of school managers or principals [1]. Utilization through a process that includes planning, organizing, directing, and controlling is called management. Management functions as follows:

1. Planning is an activity that determines the various objectives and causes of subsequent actions.

2. Organizing is the activity of dividing work between group members and making provisions in the relationships needed.

3. Actuating is the activities of moving group members to carry out work in accordance with their respective duties.

4. Controlling is an activity to adjust between the implementation and predetermined plans.

Management plus facilities and infrastructure play an important role in supporting development. With the implementation of regional autonomy, it means that the government provides opportunities for schools to take the initiative and work in accordance with the ability of each educational institution or school, including the construction of facilities and infrastructure.

Educational facilities are equipment and equipment that are directly used and support the educational process, especially the teaching and learning process, such as buildings, classrooms, tables, chairs, as well as teaching aids and media. Thus, the educational facilities will play a good role when the use of these facilities is carried out by the relevant educators optimally. According to Barnawi [2], educational infrastructure is all basic equipment that indirectly supports the implementation of the education process in schools. Therefore, educational facilities and infrastructure are a single unit supporting the implementation of a good and optimal learning and teaching process in order for all these facilities to provide meaningful contributions to the course of the education process, it should be managed properly. Management in question includes: (a) planning, (b) procurement, (c) inventory, (d) storage, (e) arrangement, (f) use, (g) maintenance and (h) deletion. 
Therefore there is a need for management of educational facilities and infrastructure [2].

Educational infrastructure is all objects or facilities that facilitate and expedite the process of education and teaching, but are indirect in nature, such as classrooms or buildings, tables, chairs, roads that exist in institutions of education. Educational facilities are all facilities that facilitate and facilitate the education and teaching process and are direct in nature, such as blackboards, books, OHPs, LCDs [3]. Facilities and infrastructure are very important supporting factors in the world of education besides educators. Education will never be able to run well without adequate facilities and infrastructure. Facilities and infrastructure will not be fulfilled without management being carried out in the relevant educational institutions and with the management of educational facilities and infrastructure will be empowered for the learning process.

Management of educational facilities and infrastructure can be describe as a process of cooperation in the utilization of all educational facilities and infrastructure effectively and efficiently [4]. In order for educational facilities to function properly, management of educational facilities and infrastructure is needed. With the management of educational facilities and infrastructure, the school will be able to manage educational facilities and infrastructure in a more conceptual and directed manner. Broadly speaking the condition of facilities and infrastructure at Wali Songo Pacet, Mojokerto Vocational High School is quite good and feasible to use so that teachers can carry out learning activities with good performance and students can get maximum learning results. The school has several buildings such as a laboratory, library, classroom, teacher's room, principal's office etc.

Based on the phenomena that have been described, the author makes an article entitled Management of Education Facilities and Infrastructure. The problem statement in this article is how to management of facilities and infrastructure at Wali Songo Pacet, Mojokerto Vocational School. Based on the formulation of the problem above the purpose of this article there is knowing how the management of facilities and infrastructure at Wali Songo Pacet, Mojokerto Vocational School.

\section{METHOD}

This study uses a qualitative approach with case study research design [5]. Data collection techniques using interview, observation, and documentation techniques. The research was carried out at Wali Songo Pacet, Mojokerto Vocational High School. The objects in this study are facilities and infrastructure at Wali Songo Pacet, Mojokerto Vocational High School. Research informants are based on the consideration that research informants can provide complete information and are relevant to the research objectives.

The design in this study uses a case study. In simple, case studies can be interpreted as a method of investigation directly with a natural setting and focus attention on an event intensively and in detail. This opinion gives the reason why the researcher chooses the method as well as the case study design because the researcher wants to examine the management process of advice and infrastructure in the school in depth and intensively so that what is desired in this study can be achieved clearly. Before this research was carried out first an informal preliminary study was carried out, this was done so that researchers knew about the state of the school in its entirety and objectively. This preliminary study was conducted by the researcher to make it easier to prepare a research plan. To get the data needed in this study. Researchers go directly to the field to observe directly the various types of activities carried out by informants at the research location and interview directly.

The presence of researchers here is trying to interact with the research subject naturally, not prominently and in a way, that is not compelling. The presence of researchers is absolutely necessary because researchers are key instruments that interact directly with the object of research. Because researchers are absolutely necessary in accordance with the principles of qualitative research, the researcher must create good relations with the object of research. The good relationship between the researcher and the object of the research is built in the form of mutual trust, understanding and the existence of effective communication links

\section{RESULTS AND DISCUSSION}

Based on the results of interviews and observations that the author did at Wali Songo Pacet, Mojokerto Vocational High School, it was found that the facilities and infrastructure at Wali Songo Pacet, Mojokerto Vocational High School were already good. Regarding land, yard and school building can be seen in the following table.

TABLE I. CONDITIONAL LAND AT WALI SONGO PACET MOJOKERTO VOCATIONAL HIGH SCHOOL

\begin{tabular}{|l|c|c|c|c|}
\hline \multicolumn{5}{|c|}{ Ownership Status } \\
\hline $\begin{array}{c}\text { Land } \\
\text { Resources }\end{array}$ & Certified & Not Certified & Used & Not Used \\
\hline Foundation & $6.290 \mathrm{~m}^{2}$ & - & $6.290 \mathrm{~m}^{2}$ & - \\
\hline Government & - & - & - & - \\
\hline Wakaf & - & - & - & - \\
\hline
\end{tabular}

Based on table 1, it can be seen that the total area is 6,290 $\mathrm{m}^{2}$, all of the land is used for teaching and learning activities. School buildings are generally in good condition, the number of classrooms used for teaching and learning is very adequate. The results of the analysis of the condition of school facilities and infrastructure can be seen in table 2 as follows.

TABLE II. CONDITIONAL FACILITIES AND INFRASTRUCTUR AT WALI SONGO PACET MOJOKERTO VOCATIONAL HIGH SCHOOL

\begin{tabular}{|l|l|c|c|}
\hline \multicolumn{3}{|c|}{ Ownership Status } \\
\hline No. & Fasilities and Inrastructure & Total & condition \\
\hline 1 & Building & 9 & Good \\
\hline 2 & Principal's office & 1 & Good \\
\hline 3 & Teacher's room & 1 & Good \\
\hline 4 & Medical Room & 1 & Good \\
\hline 5 & Guidance and Counseling Room & 1 & Good \\
\hline
\end{tabular}




\begin{tabular}{|l|l|c|c|}
\hline \multicolumn{4}{|c|}{ Ownership Status } \\
\hline No. & Fasilities and Inrastructure & Total & condition \\
\hline 6 & $\begin{array}{l}\text { Intra School Student } \\
\text { Organization Room }\end{array}$ & 1 & Good \\
\hline 7 & Islamic Prayer Room & 1 & Good \\
\hline 8 & Administration Room & 1 & Good \\
\hline 9 & Language Laboratory & 1 & Good \\
\hline 10 & Computer Laboratory & 1 & Good \\
\hline 11 & Banking Laboratory & 1 & Good \\
\hline 12 & Mini Bank Laboratory & 1 & Good \\
\hline 13 & Field ceremony & 1 & Good \\
\hline 14 & Sports field & 1 & Good \\
\hline 15 & Library & 1 & Good \\
\hline 16 & Canteen & 1 & Good \\
\hline 17 & Bathroom & 6 & Good \\
\hline 18 & Computer & 14 & Good \\
\hline 19 & HT & & Good \\
\hline
\end{tabular}

Based on table 2, it can be seen that at the Wali Songo Pacet, Mojokerto Vocational High School the existing infrastructure is very adequate in supporting the education process. So, whenever needed by school personnel always ready to use. The number of facilities owned by Wali Songo Pacet, Mojokerto Vocational High School is very relevant to the needs of students.

If it refers to the management of facilities and infrastructure proposed that management of educational facilities and infrastructure is defined as the process of cooperation in the utilization of all educational facilities and infrastructure effectively and efficiently. In order for all these facilities to contribute optimally to the education process, it must be managed properly, using management principles and functions including: (a) Planning, (b) Procurement, (c) Inventory, (d) Storage, (e) Distribution, (f) Maintenance, (g) Elimination, (h) Assessment and Supervision.

General the purpose of management of educational facilities and infrastructure is to provide professional services in the field of educational facilities and infrastructure in the framework of implementing the education process effectively and efficiently. While the specific objectives are [5]:

- Striving for the provision of educational facilities and infrastructure through careful and careful planning and procurement systems. Through the management of educational facilities and infrastructure, it is expected that all the equipment obtained by the school is high-quality facilities and infrastructure, in accordance with the needs of the school, and with efficient funds.

- Striving for proper and efficient use of facilities and infrastructure, school facilities and infrastructure, so that their existence is always in a condition that is ready to use in every need for all school personnel.

To achieve optimal results in the management of school facilities and infrastructure must apply management principles that include actions of planning, organizing, directing, and control carried out to determine and achieve the objectives that have been determined through the utilization of human resources and other sources. To be considered in the use of infrastructure, are as follows:

- Preparation of the use schedule must be avoided by clashes with other groups.

- The main school activities should be the top priority.

- Time or schedule of use should be submitted at the beginning of the school year.

- Assignment or appointment of personnel according to expertise in their fields, such as laboratory officers, libraries, operators, computers and so on.

- Scheduling the use of school infrastructure, between intracurricular activities and extracurricular activities must be clear.

Management of educational facilities and infrastructure are all arrangements for facilities and infrastructure owned by educational institutions, and arrangements are made through processes and arranged according to the order and functions of management. By applying the principles of education management advice and infrastructure consequently starting from the process of planning, procuring, inventorying, storing, distributing, maintaining, eliminating and evaluating and supervising, the school will be able to fulfill educational facilities and infrastructure well and planned. So that the standards of facilities and infrastructure established by BNSP can be achieved, which will then automatically improve the quality of learning and at the same time affect the fulfillment of other education standards.

Based on the research findings, an inventory of infrastructure facilities was carried out aimed at facilitating reporting. This is in the day-to-day implementation of the headmaster. The administrator can designate his character or the teachers to carry out these tasks and responsibilities. School, namely daily maintenance and periodic repairs [6][7].

Based on the results of observations and interviews at Wali Songo Pacet, Mojokerto Vocational High School, Planning at the Wali Songo Pacet, Mojokerto Vocational High School was carried out by reexamining the equipment in the school every year. Thus, it can only determine the equipment needed. Procurement is done once a year to support the implementation of teaching and learning activities must be carried out properly and correctly. The smoothness of activities in the teaching and learning process will bring maximum results, when in the procurement process really pay attention to the most basic needs in supporting the success of teaching and learning activities.

This is supported by a statement expressed Alimi et.all. which essentially states that the provision of educational facilities and infrastructure is intended to meet school needs [8]. The statements that are in accordance with the above findings are then essentially stating that the functions of facilities and infrastructure must be effective in terms of the provision of educational facilities and infrastructure in accordance with predetermined needs and can provide benefits as much as the 
amount for educational institutions in general and specifically for students.

Maintenance of facilities and infrastructure at the Wali Songo Pacet, Mojokerto Vocational High School, is the responsibility of the entire academic community. This is done so that existing facilities and infrastructure are always in good condition, maintained and not easily damaged. In maintaining school facilities and infrastructure awareness of all school members is needed to have a great sense of responsibility for the facilities and infrastructure that the School has. This is supported by Gonzales, the point of which is that with the care being taken every day educational facilities and infrastructure can be well maintained and able to support the learning process. Furthermore, the findings above are supported by the theory of Gunawan and Benty which essentially states that daily maintenance to condition facilities and infrastructure is ready to use and can reduce the risk of damage.

The narrative of the deputy headmaster of the facilities and infrastructure section is the same as the results of interviews that the author did with the principal, that in the stages of providing the goods code for existing facilities and infrastructure the process is being carried out, because in providing the code the product must go through a long procedure and require a lot time in the activity. Based on the research findings, an inventory of infrastructure facilities was carried out aimed at facilitating reporting. This is in accordance with what was said by Stoop that in the day-to-day implementation of the headmaster, the administrator can designate his character or the teachers to carry out these tasks and responsibilities. School namely daily maintenance and periodic repairs.

The elimination of facilities and infrastructure is an activity to release facilities and infrastructure from the applicable accountability with justifiable reasons [8]. As one of the activities in the management of educational equipment in schools, the principal has the authority to do the elimination of school supplies. However, school equipment to be removed must have deletion requirements, such as being damaged or not in accordance with school needs, stolen, not having a clear function. The principal and his staff should classify and record items to be deleted.

The elimination of educational facilities and infrastructure must go through a deletion procedure, the existing procedure such as giving out deletion to each school, then the school records what items will be removed, then after recording the items reported to the education office the field review is conducted by the BPK. Essentially states that in the elimination procedure must pay attention to steps such as: the formation of a team, identifying the types of goods to be removed, recording the facilities and infrastructure to be removed, and approval from the school [9].
Educational facilities and infrastructure are very important components in every educational activity specially to support success in teaching and learning activities, so in implementing at Wali Songo Pacet, Mojokerto Vocational High School as optimal as possible in managing infrastructure by being handled by employees and assisted by teachers. With the advancement of education, the Wali Songo Pacet, Mojokerto Vocational High School always conducts updates in all fields, one of which is in the field of infrastructural.

\section{CONCLUSION}

Based on the results of interviews and observations made on Wali Songo Pacet, Mojokerto Vocational High Schools already have adequate facilities and infrastructure. This can be seen from the complete facilities and infrastructure owned by Pacet Wali Songo Vocational High School. The facilities and infrastructure are directly under the supervision of the facilities and infrastructure which aim to be more effective and efficient. The process of managing educational infrastructure, Pacet Wali Songo Vocational High School is carried out sequentially, starting with planning, procurement, maintenance, inventory and deletion. The process is done so that the preschool facilities at the Pacet Wali Songo Vocational High School are always in good, orderly and orderly conditions.

The government prepares minimum standards for facilities and infrastructure for schools but has not yet prepared sufficient and adequate funding allocations according to the allocation of funds mandated by the law, so that participation and assistance from the community are still needed to support the fulfillment of school facilities and infrastructure needs

\section{REFERENCES}

[1] P. A. Obicci, Risk management strategies in public-private partnerships. IGI Global, 2017.

[2] M. Barnawi \& Arifin, "Manajemen Sarana dan Prasarana Sekolah," Jogjakarta: Ar-Ruzz Media, 2012.

[3] R. Bauscher and E. M. Poe, Educational facilities: Planning, modernization, and management. Rowman \& Littlefield, 2018.

[4] C. L. Uline and F. E. Crampton, "Spending on school infrastructure: does money matter?," J. Educ. Adm., 2009.

[5] R. K. Yin, Qualitative research from start to finish. Guilford Publications, 2015.

[6] L. Educators, "of Leadership Education,” Education, vol. 5, no. 2, p. 144, 2010.

[7] D. W. Chapman and S. A. Burchfield, "How headmasters perceive their role: A case study in Botswana," Int. Rev. Educ., vol. 40, no. 6, pp. 401419, 1994.

[8] O. S. Alimi, G. B. Ehinola, and F. O. Alabi, "School Types, Facilities and Academic Performance of Students in Senior Secondary Schools in Ondo State, Nigeria.," Int. Educ. Stud., vol. 5, no. 3, pp. 44-48, 2012.

[9] T. Bush, L. Bell, R. Bolam, R. Glatter, and P. M. Ribbins, Educational management: Redefining theory, policy and practice. SAGE, 1999. 